\title{
COMBINING ABILITY AS A CRITERION FOR WHEAT PARENTS SELECTION
}

\author{
Alan Junior de Pelegrin ${ }^{1}$, Maicon Nardino ${ }^{2}$, Ivan Ricardo Carvalho ${ }^{3}$, Vinicius Jardel Szareski ${ }^{4}$, \\ Mauricio Ferrari ${ }^{4}$, Giordano Gelain Conte ${ }^{1}$, Antonio Costa de Oliveira ${ }^{1}$, Velci Queiroz de Souza ${ }^{5}$, \\ Luciano Carlos da Maia ${ }^{1}$ \\ 1) Plant Genomics and Breeding Center, Federal University of Pelotas, Box 354, Pelotas, RS, 96001-970, Brazil; \\ 2) Departament of Agronomy, Federal University Viçosa, Viçosa - MG, 36570-900, Brazil; \\ 3) Universidade Regional do Noroeste do Estado do RioGrande do Sul, Rua do Comércio, 3000, 98700-000 Ijuí, RS, Brazil; \\ 4) SLC Agricultural, Pamplona Farm Box 84, Luziânia, GO, 72800-970, Brazil; \\ 5) Federal University of Pampa, Bagé, RS, 96400-100, Brazil.
}

Correspondent author: Maicon Nardino (nardino@ufv.br)

\begin{abstract}
The breeding program success is related to the combining ability between parents. The aim of this work was to evaluate the combining ability in a wheat full diallel on $\mathrm{F}_{2}$ generation, as a selection criterion of promising parents in the formation of segregating population. Five wheat genotypes were used (Tbio Mestre, Mirante, Quartzo, Pampeano and Fundacep Horizonte) which were subjected to artificial crossings following full diallelic model, resulting in 20 hybrids combinations. In the 2015 crop season, the $20 \mathrm{~F}_{2}$ populations and the five parents were conducted in Federer augmented blocks in four repetitions. The Fundacep Horizonte parent presents high combining ability for plant grain mass. Quartzo and Mirante maximize the spikelet number per head and the head length, Tbio Mestre has lower head insertion height, plants stature and spacing between head spikelets. Reciprocal effects were detected, indicating maternal inheritance on the evaluated traits.
\end{abstract}

Keywords: Triticum aestivum L., maternal effect, segregating populations, diallelic model. 


\section{Introduction}

The success of plant breeding programs is dependent on the combining ability between parents, which is a determinant factor for the formation of superior segregating populations (Kurek et al., 2001). In this way, the identification of high combining ability constitutes a crucial step in the wheat breeding process (Kotzamanidis et al., 2008).

Annually, in the breeding programs many segregating populations are formed and evaluated. However not all combinations possess enough genetic potential to originate superior genotypes. It does difficult the crop genetic progress, because part of the resources used in the formation, of segregant populations will not present satisfying results, harming the breeding programs efficacy.

The diallelic analysis allows the study and selection of the best parental combinations, through evaluating the parental combining ability in the generated progenies, which seeks to identify parents with high allelic complementarity. Furthermore, it allows determining which is the predominant gene action in the trait is expression (Cruz et al., 2012).

It supports the selection of the populations conducting method and in the selection criteria to be elected by the breeder. Used to be limited to crosspollinated species breeding, this method is being successfully used in self-pollinated crops, with significant results for crops as oat (Valério et al., 2009; Ribeiro et al., 2011) and wheat (Schmidt, 2008; Pimentel et al., 2013).

The $F_{2}$ and $F_{3}$ generations can be efficiently used in studies of wheat combining ability since they result in better predictions than the $F_{1}$ generation. When applied in advanced generations, the combining ability studies conducted in the $F_{2}$ or $\mathrm{F}_{3}$ generations offers, the opportunity to test the genotypes in different environments, what allows one to obtain information regarding a possible environment $\times$ combining ability (Bhullar et al., 1979; Masood and Kronstad, 2000). In this context, this work aim was to evaluate the combining ability in a wheat full diallel in the $\mathrm{F}_{2}$ generation as criteria for the selection of promising parents to the formation of segregating populations.

\section{Materials and methods}

\section{Plant material}

Five wheat genotypes were used (Tbio Mestre, Mirante, Quartzo, Pampeano and Cep Horizonte) (Table 1 Supplementary), and submitted to artificial crossings following full diallelic model, resulting in 20 hybrid combinations.

The experiment was realized in 2015, at the Genetic Breeding and Plants Production Laboratory - LMGPP's experimental field, linked to the Santa Maria Federal University Campus Frederico Westphalen - RS, located at the $27^{\circ} 23^{\prime} 48,17^{\prime \prime}$ 'S and $53^{\circ} 25^{\prime} 34,82^{\prime \prime} \mathrm{O}$ coordinates and 460 meters of altitude. The soil classification is dystrophic red latosol (Santos et al., 2006) and Köppen characterizes the climate as Cfa subtropical (Alvares et al., 2013).

The parental selection was performed based on attributes of high yield potential, grain industrial quality for bakery and phenotypic adaptability or stability to the growing conditions.

The artificial hybridizations were performed in greenhouse in 2013, aiming for obtaining the $F_{1}$ generation. The seeds in each crossing were sown on field to the generation advance in the 2014 year. The $\mathrm{F}_{2}$ populations were obtained by selfpollination of $F_{1}$ plants, which after the harvest were preserved to compose the 2015 field experiment.

\section{Experimental design}

At the 2015 crop season, the $20 \mathrm{~F}_{2}$ populations and the five parents were conducted in Federer augmented blocks (Federer, 1956), where the parents where disposed in four repetitions. The experiment was installed in July 2015, the recommended wheat-sowing season at the municipality of Frederico Westphalen - RS, according to the agroclimatic zoning for the wheat crop. Every population was sown in line spaced by $0.6 \mathrm{~m}$ and $0.25 \mathrm{~m}$ between plants, for each experimental unit the use was patterned for 50 properly spaced plants.

\section{Soil management}

Fertilizer application was $200 \mathrm{~kg} \mathrm{ha}^{-1}$ of NPK (08-24-12), $90 \mathrm{~kg} \mathrm{ha}^{-1}$ of urea, divided in two 
applications (early tillering and jointing). Weeds pest and disease management were performed according to wheat technical recommendations (RCBPTT, 2014).

\section{Assessed traits}

The following traits were evaluated: Plant Grain Mass (PGM): measured the grains total mass per plant, the results in grams $(\mathrm{g})$; Head Insertion Height (HIH): measured the distance between the soil surface to the head insertion, in centimeters $(\mathrm{cm})$; Plant Height $(\mathrm{PH})$ : measured the distance between the soil surface to the superior end of the head, results in centimeters $(\mathrm{cm})$; Number of Fertile Tillers (NFT): four weeks after anthesis it was noted the number of exteriorized tillers from the head; Spacing Between Head Spikelets (SBHS): measured the distance between head spikelets, results expressed in millimeters $(\mathrm{mm})$; Spikelet Number (SN): obtained by counting the head spikelets number, expressed in unit; and Head Length (HL): the measure between the head basis and the superior extremity, expressed in centimeter (cm).

\section{Statistical analysis}

For the diallelic analysis the Griffing procedure (1956), method I, model I, where the $n^{2}$ combinations are included, through the statistic model:

$$
\widehat{\mathrm{Y}}_{\mathrm{ij}}=\mathrm{m}+\hat{\mathrm{g}}_{\mathrm{i}}+\hat{\mathrm{g}}_{\mathrm{j}}+\widehat{\mathrm{S}}_{\mathrm{ij}}+\hat{\mathrm{r}}_{\mathrm{ij}}+\widehat{\varepsilon}_{\mathrm{ij}}
$$

Where: $\hat{Y}_{i j}$ : hybrid combination mean value $(i$ $\# j)$ or the parent $(i=j) ; m$ : overall mean; $\hat{g}_{i}$ and $\hat{g}_{j}$ : effects of the general combining ability of the i-th and the j-th parent, respectively; $\widehat{S}_{i j}$ : effect of the specific combining ability for the crosses between parents of order $i$ and $j ; \hat{r}_{i j}$ : reciprocal effect for the crossings between parents of order $i$ and $j ; \hat{\varepsilon}_{i j}$ : experimental error.

The statistics analysis were performed with SAS software support through macro DIALLELSAS05 (Zhang et al., 2005).

\section{Results and discussion Traits characterization}

The variance analysis in $\mathrm{P}<0.05$ revealed significant effect to the genotype factor for all the evaluated traits. This significant effect verified shows the presence of genetic variability in the crossings, being the result of additive and not additive gene effects, what enables one to obtain transgressive families and subsequently new cultivars (Silva et al., 2004).

Table 2. Resume of the diallelic variant analysis for the seven agronomic traits of wheat, according to Griffing model I (1956).

\begin{tabular}{|c|c|c|c|c|c|c|c|c|}
\hline \multirow{2}{*}{ VF } & \multicolumn{8}{|c|}{ Mean Square } \\
\hline & DF & PGM & $\mathrm{HIH}$ & $\mathrm{PH}$ & NFT & SBHS & SN & $\mathrm{HL}$ \\
\hline Block & 3 & 264.10 & 81.48 & 153.29 & 454.82 & 5.79 & 13.55 & 13.00 \\
\hline Genotype & 24 & $76.98^{*}$ & $789.71^{*}$ & $869.25^{*}$ & $625.67^{*}$ & $5.70^{*}$ & $38.85^{\star}$ & $36.31^{*}$ \\
\hline GCA & 4 & $57.30^{*}$ & $3,051.26^{*}$ & $3,566.88^{*}$ & $772.06^{*}$ & $6.23^{*}$ & $38.96^{*}$ & $39.18^{*}$ \\
\hline SCA & 10 & $63.97^{*}$ & $372.94^{*}$ & $347.25^{*}$ & $545.97^{*}$ & $3.59^{*}$ & $43.91^{*}$ & $25.64^{*}$ \\
\hline REC & 10 & $48.48^{*}$ & $295.19^{*}$ & $290.02^{*}$ & $655.58^{*}$ & $7.82^{*}$ & $34.22^{*}$ & $44.78^{*}$ \\
\hline MAT & 4 & $62.79^{*}$ & $219.8^{*}$ & $210.26^{*}$ & $465.13^{*}$ & $4.86^{*}$ & $52.57^{*}$ & $35.12^{*}$ \\
\hline NMAT & 6 & $38.94^{*}$ & $345.44^{*}$ & $343.19^{*}$ & $782.56^{*}$ & $9.80^{*}$ & $21.99^{*}$ & $51.23^{*}$ \\
\hline Error & 1263 & 17.65 & 38.21 & $46.20^{*}$ & 135.97 & 0.46 & 4.69 & 4.90 \\
\hline VC (\%) & - & 62.6 & 11.6 & 10.88 & 48.11 & 10.88 & 14.26 & 24.09 \\
\hline GCA $(\%)$ & - & 26.38 & 76.59 & 80.43 & 36.13 & 40.94 & 26.20 & 37.94 \\
\hline
\end{tabular}


The genotype sum of squares were disclosed in general combining ability (GCA) and the specific combining ability (SCA). The presence of significance to the GCA reflects in the importance of the additive genic effects in the evaluated traits expression to the set of tested genotypes (Pádua et al., 2010). At wheat crops, the use of pure lines are prioritized, where having control over the parents GCA is fundamental for breeders, because it refers to the genotype potentials to contribute thru genes with additive effect for the character expression, a fraction that really interests to the researcher as it is passed throughout generations (Ramalho et al., 1993). It is pertinent to highlight the presence of the GCA significance for all traits, mostly for the PGM, characterized with the major research lines effort of this breeding program, since it indicates that, in these traits exist at least one superior parent of all, regarding to its mean performance at combinations (Rodrigues et al., 1998).

The SCA demonstrated significant effect on PGM, HIH, PH, NFT, SBHS, SH, HL traits, indicating that the obtained combination differs itself and the gene effects originated from the nonadditivity reveals prominence above all traits (Sibiya et al., 2011; Rocha et al., 2014). Thus, to all circumstances these effects imply the breeder cautions in the progeny selection at this generation, because the observed traits expression can be minimized throughout generations.

The reciprocal cross is defined as the one in which the parent is used sometimes as pollen receptor (female), sometimes as a pollen donor (male). Therefore, as a function of the result between the cross and its reciprocal effect it is possible to make inference about the predominating heritage for that trait. If nuclear genes control a trait heritage, the result from a crossing and its reciprocal will be similar or identic. However, if a trait is consequence of cytoplasmic effects, the results from reciprocal crossings will be different, because the descendants from each crossing will have a tendency to the female parent phenotype, which has contributed with cytoplasmic organelles (Ramalho et al., 2012).

The reciprocal effect (REC) indicates which genotype must be used as male parent or as female parent in a hybrid combination, according to its performance as pollen donor or receptor (Rocha et al., 2014). Thus, it is possible to observe that all studied traits displayed significant reciprocal effect (Table 2). This effect can be divided in maternal effect (MAT), ascribed to genetic cytoplasmic factors and non-maternal effect (NMAT) that can be explained through interactions between nuclear genes and cytoplasmic genes effects (Mukanga et al., 2010).

When the reciprocal effect occurs, as a function of maternal components, it can remain during the generations advance and has potential to be explored. However, if the reciprocal effect is due to a non-maternal component, it can be lost during the breeding generations. Therefore, it is necessary to consider the nuclear and non-nuclear factors in the selection of plants, mostly when a reciprocal effect is verified (Wu and Mathenson, 2001).

\section{GCA relative contribution}

The GCA contribution was 76.59 and $80.43 \%$ for $\mathrm{HIH}$ and $\mathrm{PH}$ (Table 2) respectively, revealing that the additive gene variation was the most relevant component for these traits, as the GCA effects were higher than the SCA effects (Sibiya et al., 2011). However, regarding to the GCA contribution the PGM (26.38\%), NFT (36.12\%), SBHS (40.94\%), SN (26.20\%) and HL (37.94\%), reveals more contribution from SCA to this traits expression. This behavior shows the importance of non-additive effects for these traits expression.

The genotype combining ability, in the presence of complementing genes, is responsible for the success of breeding programs, where the selection of used to develop the segregating populations is essential to obtain superior genotypes (Lorencetti et al., 2005). According to Jung et al. (2007), the parents al selection based only in the phenotypic evaluation is scant to ensure the production of genotypes with high transgressive segregant rates. Thus, parental selection must be performed based on the genetic information and on the potential of the parents combining ability with potential to produce favorable recombination at high frequency (Allard, 1999).

\section{Estimates of general combining ability (GCA)}

Relating to the estimates of GCA effects to the plants grain mass the Cep Horizonte genotype presented with positive magnitude (0.35) to the trait, 
revealing that the intercrossing of this genotype with other groups enables on to gather more favorable alleles to express higher head grain mass. The plant grain mass compose a fundamental trait to determine the grain yield, mostly in condition of low head number per area unit (Gondim et al., 2008).

Table 3. Estimates of general combining ability (GCA) from five parents related to seven agronomic traits studied in wheat.

\begin{tabular}{cccccccc}
\hline \multirow{2}{*}{ Genotypes } & \multicolumn{7}{c}{$\hat{g}_{i}^{\dagger}$} \\
\cline { 2 - 7 } & PGM & HIH & PH & NFT & SBHS & SN & HL \\
\hline Tbio Mestre & 0.21 & $-4.25^{*}$ & $-4.59^{*}$ & -0.37 & $-0.19^{*}$ & $-0.38^{*}$ & $-0.33^{*}$ \\
\hline Mirante & $-0.18^{*}$ & $1.22^{*}$ & $1.58^{*}$ & $1.31^{*}$ & 0.04 & $0.17^{*}$ & $0.35^{*}$ \\
\hline Quartzo & 0.08 & $0.59^{*}$ & $0.67^{*}$ & $-1.12^{*}$ & 0.04 & $0.24^{*}$ & 0.07 \\
\hline Pampeano & $-0.46^{*}$ & $1.18^{*}$ & $1.29^{*}$ & $-1.08^{*}$ & 0.04 & 0.16 & 0.11 \\
\hline Cep Horizonte & $0.35^{*}$ & $1.25^{*}$ & $1.05^{*}$ & $1.26^{*}$ & $0.07^{*}$ & $-0.20^{*}$ & $-0.20^{*}$ \\
\hline
\end{tabular}

*Estimates difference 0 with $\mathrm{p}<0.05$ significance level by $\mathrm{t}$ test; ${ }^{\dagger} \hat{g}_{i}-$ General ability combination effects; PGM - Plant Grains Mass; HIH Head Insertion Height; PH - Plant Height; NFT - Number of Fertile Tillers; SBHS - Spacing Between Head Spikelets; SN - Spikelets Number and HL - Head Length.

Regarding to the GCA effects to head insertion height $(\mathrm{HIH})$ and plant height $(\mathrm{PH})$, the genotypes Mirante, Quartzo, Pampeano and Cep Horizonte had the higher positive allelic frequency of additive effects increasing the traits. The elevation of the head insertion height is not an important trait, mostly in wheat genotypes with low stem lodging resistance (Souza et al., 2013). Thus, the fact that the head is positioned higher than the soil level, exert a higher force to topping, and can cause plants lodging with harvesting losses.

The genotype Tbio Mestre exhibited GCA estimates with negative effects to HIH $\left(\hat{g}_{i}=-4.25\right)$ and $\mathrm{PH}\left(\hat{\mathrm{g}}_{i}=-4.59\right)$, a factor that allow use this genotype in intercrossings with other lines groups to reduce the head insertion height and wheat height. The low height is an essential characteristic due to its higher resistance to lodging (Scheeren et al., 1981). Several studies reveal that resistance to lodging constitutes one of the most influent factors to grain yield (Borojevic, 1968; Laude and Pauli, 1956, Vogel et al., 1956).

Furthermore, other advantages of low height wheat genotypes is the pronounced yield potential due to increasing the number and capability of fertile tillers, combined with high fertility of head spikelets (Plarre, 1975), more tolerance to damage caused by precipitation a wind (Borojevic, 1968) and the increase of the relation kernel/straw (Carvalho and Dotto, 1975).

Regarding to the GCA effect estimates to the number of fertile tillers trait, negative effects occurred in the genotypes Quartzo $\left(\hat{g}_{i}=-1.12\right)$ and Pampeano $\left(\hat{g}_{i}=-1.08\right)$. The genotypes Mirante $\left(\hat{g}_{i}=\right.$ $1.31)$ and Cep Horizonte $\left(\hat{g}_{i}=1.26\right)$ attained positive effects from GCA, where the crossings from this genotypes can contribute to the number of fertile tillers increase.

The tillering potential is a trait associated to the adaptation to unfavorable environments, besides representing one of the most important grain yield compounds (Valério et al., 2009). Regarding the spacing between head spikelets, the genotype Tbio Mestre revealed reduction on effects estimates of GCA for this trait, which can be used in intercrossings aiming to reduce the spacing between head spikelets.

Owing to the effects evaluation on GCA for number of spikelets per head, the genotypes Quartzo $\left(\hat{g}_{i}=0.24\right)$ and Mirante $\left(\hat{g}_{i}=0.17\right)$ showed positive magnitudes, allowing to use them in intercrossings with other groups, leading to the acumulation of favorable alleles that contribute to elevate the number of spikelets per head.

The increasing of this trait is an efficient strategy to elevate the grain yield in wheat, which is associated to the increase in number of grains per head, considered an important grain yield component (Rodrigues et al., 2011). Concerning head length, the genotypes Tbio Mestre $\left(\hat{g}_{i}=-0.33\right)$ and Cep Horizonte $\left(\hat{g}_{i}=-0.20\right)$ reduced its GCA estimates for this trait. The genotype Mirante $\left(\hat{g}_{i}=\right.$ 0.35) presented positive effect to the GCA estimates, allowing the use of this genotype in 
crossings with other genetic constitutions as an advantage to increase the expression of this trait. The head length is described as a major agronomic trait and must be considered in the wheat breeding aiming at major grain yield components.

\section{Estimates of specific combining ability (SCA)}

The SCA effects can be interpreted as a deviation presented by a hybrid in relation to its expected performance, based on its parents general abilities (Gomes et al., 2000). Thus, the greatest SCA values are credited to genotypes with more dissimilarities in dominant allele frequencies, although they are also influenced by the mean genic frequency of the diallel (Rocha et al., 2014).

Significant positive effects from SCA to the trait PGM, in the crossing Tbio Mestre $\times$ Pampeano $\left(\widehat{S}_{i j}=0.94\right)$ and Mirante $\times$ Cep Horizonte $\left(\widehat{S}_{i j}=0.51\right)$ were observed. For the $\mathrm{HIH}$ and $\mathrm{PH}$, negative effects of SCA in the crossings Mirante $\times$ Pampeano $\left(\hat{S}_{i j}=-2.81\right.$ and $\hat{S}_{i j}=-2.40$, respectively), Tbio Mestre $\times$ Pampeano $\left(\widehat{S}_{i j}=-2.10\right.$ and $\widehat{S}_{i j}=-2.02$, respectively $)$ and Quartzo $\times$ Cep Horizonte $\left(\widehat{S}_{i j}=-2.17\right.$ and $\widehat{S}_{i j}=$. 1.80 , respectively). For TN, positive effects from SCA in the crossing Pampeano $\times$ Cep Horizonte (3.21) were observed. For SBHS, the crossings Tbio Mestre $\times$ Mirante $\left(\widehat{S}_{i j}=-0.26\right)$ and Tbio Mestre $\times$ Quartzo $\left(\hat{S}_{i j}=-0.12\right)$ showed negative effects from $\mathrm{SCA}$. For the trait SN, a positive effect from SCA in the crossing Mirante $\times$ Cep Horizonte $\left(\widehat{S}_{i j}=0.65\right)$ was observed. For HL, the crossings Mirante $\times$ Pampeano $\left(\hat{S}_{i j}=0.41\right)$ and Quartzo $\times$ Cep Horizonte $\left(\widehat{S}_{i j}=0.38\right)$ revealed positive estimates from SCA.

Table 4. Estimates of specific combining ability effects for seven wheat agronomic traits resulted from full diallel crossings $(5 \times 5)$.

\begin{tabular}{|c|c|c|c|c|c|c|c|c|c|}
\hline \multicolumn{3}{|c|}{ Genotypes } & \multicolumn{7}{|c|}{$\hat{S}_{i j}$} \\
\hline It & & $J$ & PGM & HIH & $\mathrm{PH}$ & NFT & SBHS & SN & $\mathrm{HL}$ \\
\hline Tbio Mestre & $x$ & Mirante & 0.68 & $1.63^{*}$ & $1.80^{*}$ & 0.82 & $-0.26^{*}$ & 0.08 & 0.17 \\
\hline Tbio Mestre & $x$ & Quartzo & $-1.31^{*}$ & $2.23^{*}$ & 0.30 & 0.74 & $-0.12^{*}$ & $-0.49^{*}$ & 0.07 \\
\hline Tbio Mestre & $x$ & Pampeano & $0.94^{*}$ & $-2.10^{*}$ & $-2.02^{*}$ & 0.45 & $0.13^{*}$ & -0.25 & 0.08 \\
\hline Tbio Mestre & $x$ & Cep Horizonte & -0.11 & 0.24 & 0.57 & -1.41 & -0.09 & 0.26 & 0.34 \\
\hline Mirante & $x$ & Quartzo & 0.08 & 0.10 & -0.66 & -0.24 & $0.25^{*}$ & $-0.82^{*}$ & $-0.77^{*}$ \\
\hline Mirante & $x$ & Pampeano & $-1.21^{*}$ & $-2.81^{*}$ & $-2.40^{*}$ & $-4.14^{*}$ & 0.06 & 0.01 & $0.41^{*}$ \\
\hline Mirante & $x$ & Cep Horizonte & $0.51^{*}$ & $2.35^{*}$ & $2.58^{*}$ & 1.46 & $0.22^{*}$ & $0.65^{*}$ & 0.23 \\
\hline Quartzo & $x$ & Pampeano & -0.23 & 0.74 & 0.83 & $-1.74^{*}$ & -0.07 & 0.33 & 0.09 \\
\hline Quartzo & $x$ & Cep Horizonte & $0.87^{*}$ & $-2.17^{*}$ & $-1.80^{*}$ & 1.25 & -0.02 & $-0.97^{*}$ & $0.38^{*}$ \\
\hline Pampeano & $x$ & Cep Horizonte & $0.34^{*}$ & $1.92^{*}$ & 0.90 & $3.21^{*}$ & -0.08 & 0.06 & $-1.02^{*}$ \\
\hline \multicolumn{3}{|c|}{ Genotypes } & \multicolumn{7}{|c|}{$\hat{r}_{i j}$} \\
\hline$J$ & & $I^{\dagger}$ & PGM & HIH & $\mathrm{PH}$ & NFT & SBHS & SN & PL \\
\hline Tbio Mestre & $x$ & Mirante & -0.78 & 0.88 & 0.97 & 0.75 & $0.18^{*}$ & $-0.48^{*}$ & 0.09 \\
\hline Tbio Mestre & $x$ & Quartzo & 0.02 & $-1.31^{*}$ & -1.10 & -0.85 & $0.39^{*}$ & 0.24 & 0.21 \\
\hline Tbio Mestre & $x$ & Pampeano & -0.75 & $-3.16^{*}$ & $-3.60^{*}$ & -1.76 & -0.02 & 0.11 & $-0.44^{*}$ \\
\hline Tbio Mestre & $x$ & Cep Horizonte & $-1.24^{*}$ & $1.59^{*}$ & 1.27 & $-5.44^{*}$ & $0.30^{*}$ & 0.19 & -0.32 \\
\hline Mirante & $x$ & Quartzo & 0.12 & -0.15 & 0.59 & 1.01 & -0.10 & $1.26^{*}$ & $0.74^{*}$ \\
\hline Mirante & $x$ & Pampeano & 0.16 & $1.92^{*}$ & $2.04^{*}$ & 1.34 & $-0.15^{*}$ & 0.04 & 0.12 \\
\hline Mirante & $x$ & Cep Horizonte & 0.15 & 0.01 & 0.47 & 0.96 & $0.25^{\star}$ & $0.98^{*}$ & $0.46^{*}$ \\
\hline Quartzo & $x$ & Pampeano & $-1.34^{*}$ & $-1.78^{*}$ & $-2.32^{*}$ & $-4.49^{*}$ & -0.02 & $0.65^{*}$ & $-0.54^{*}$ \\
\hline Quartzo & $x$ & Cep Horizonte & 0.46 & $-1.37^{*}$ & -1.32 & $2.75^{*}$ & $0.29^{*}$ & -0.20 & 0.05 \\
\hline Pampeano & $x$ & Cep Horizonte & -0.74 & $2.40^{*}$ & 0.65 & 0.35 & $-0.57^{*}$ & 0.23 & $-1.75^{*}$ \\
\hline
\end{tabular}

*Estimates difference 0 with $\mathrm{p}<0.05$ significance level by $\mathrm{t}$ test; ${ }^{\dagger} I$ - Female parent; $J$ - Male parent; $\hat{S}_{i j}$ - Specific combining ability effects; $\hat{r}_{i j}$ - Reciprocal Effect; PGM - Plant Grain Mass; HIH - Head Insertion Height; PH - Plants Height; NFT - Number of Fertile Tillers; SBHS - Spacing Between Head Spikelets; SN - Spikelets Number and HL - Head Length. 
The estimates of SCA positive effects indicates that the dominant deviances are positive, wich means, they remit to dominant alleles that contribute to increase the expression of the trait. However the SCA values near to zero, or nonsignificant, reveal that the heterosis on segregating hybrid/population will also be near to zero. According to Kostetzer et al. (2009), when the significant effects from SCA were positive, it indicated that these combinations showed increments, and when negative they intended to reduce the trait magnitude, whom cannot be explained by the parents mean and its general combining ability.

\section{Estimates of reciprocal, maternal and non-maternal effects}

The estimates of reciprocal effects and the deployment results are disposed in tables 4 and 5. In reason to the present relation of these effects, it will be described and discussed simultaneously. Reciprocal combinations that could increase the plant grain mass were not identified, however, the crossing Tbio Mestre $\times$ Cep Horizonte $\left(\hat{r}_{i j}=-1.24\right)$, having the Cep Horizonte as female parent and the crossing Quartzo $\times$ Pampeano $\left(\hat{r}_{i j}=-1.34\right)$, having Pampeano as female parent (Table 4), revealed negative effects, not being favorable to this trait aspects, because it reduces the wheat plant grain mass.

The negative and significant reciprocal effect for Tbio Mestre $\times$ Cep Horizonte, possibly occurred as a function of the significant negative maternal effect from Tbio Mestre parent (-0.55). On the other hand, to the Quartzo $\times$ Pampeano combination, the significant negative reciprocal effects can be related with non-maternal gene effects that are negative and significant to Quartzo $\times$ Pampeano combination (0.78 ). These results are supported by previous findings (Schmidt 2008), which defined the combining ability and reciprocal effects of important traits in six wheat cultivars, verified that the plant grain mass was highly influenced by the expression of maternal effects manifestation, of extra chromosomal inheritance interaction between nuclear and cytoplasmic genes.

Table 5. Estimates of maternal (MAT) and non-maternal (NMAT) effects for seven agronomic wheat traits from parents and crossings in a full diallel $(5 \times 5)$.

\begin{tabular}{|c|c|c|c|c|c|c|c|}
\hline \multirow{2}{*}{ Genotypes } & \multicolumn{7}{|c|}{ Maternal Effect } \\
\hline & PGM & $\mathrm{HIH}$ & $\mathrm{PH}$ & NFT & SBHS & SN & HL \\
\hline Tbio Mestre & $-0.55^{*}$ & -0.40 & -0.49 & $-1.46^{*}$ & $0.17^{*}$ & 0.01 & -0.09 \\
\hline Mirante & 0.24 & 0.18 & 0.43 & 0.51 & -0.04 & $0.55^{*}$ & $0.25^{*}$ \\
\hline Quartzo & -0.16 & -0.34 & $-0.63^{*}$ & -0.38 & -0.01 & $-0.21^{*}$ & $-0.29 *$ \\
\hline Pampeano & 0.20 & $1.08^{*}$ & $0.90^{*}$ & $1.05^{*}$ & $-0.07^{*}$ & -0.11 & $-0.18^{*}$ \\
\hline Cep Horizonte & 0.27 & $-0.53^{*}$ & -0.21 & 0.27 & $-0.05^{\star}$ & $-0.24^{*}$ & $0.31^{*}$ \\
\hline Parents & \multirow{2}{*}{\multicolumn{7}{|c|}{ Non-Maternal Effect }} \\
\hline$J$ & & & & & & & \\
\hline Tbio Mestre $\times$ Mirante & 0.01 & $1.46^{*}$ & $1.88^{*}$ & $2.72^{*}$ & -0.03 & 0.06 & $0.43^{*}$ \\
\hline Tbio Mestre × Quartzo & 0.41 & $-1.25^{\star}$ & $-1.23^{*}$ & 0.23 & $0.22^{*}$ & 0.02 & 0.01 \\
\hline Tbio Mestre $\times$ Pampeano & -0.01 & $-1.68^{*}$ & $-2.20^{*}$ & 0.75 & $-0.26^{*}$ & -0.01 & $-0.53^{*}$ \\
\hline Tbio Mestre $\times$ Cep Horizonte & -0.42 & $1.46^{*}$ & $1.55^{\star}$ & $-3.70^{*}$ & -0.05 & -0.06 & 0.08 \\
\hline Mirante $\times$ Quartzo & -0.29 & -0.67 & -0.46 & 0.12 & -0.07 & $0.50^{*}$ & 0.21 \\
\hline Mirante $\times$ Pampeano & 0.11 & $2.82^{*}$ & $2.52^{*}$ & $1.88^{*}$ & $-0.19^{*}$ & $-0.63^{*}$ & -0.30 \\
\hline Mirante $\times$ Cep Horizonte & 0.18 & -0.70 & -0.17 & 0.72 & $0.23^{*}$ & 0.19 & $0.53^{*}$ \\
\hline Quartzo x Pampeano & $-0.78^{*}$ & -0.36 & -0.79 & $-3.06^{*}$ & -0.09 & $0.75^{\star}$ & $-0.43^{*}$ \\
\hline Quartzo × Cep Horizonte & $0.90^{*}$ & $-1.56^{*}$ & -0.91 & $3.41^{*}$ & $0.24^{*}$ & -0.23 & $0.65^{*}$ \\
\hline Pampeano × Cep Horizonte & $-0.67^{*}$ & $0.79^{*}$ & -0.47 & -0.43 & $-0.55^{*}$ & 0.10 & $-1.26^{*}$ \\
\hline
\end{tabular}

*Estimates difference 0 with $\mathrm{p}<0.05$ significance level by $\mathrm{t}$ test; ${ }^{\dagger} I-$ Female parent; $J$ - Male parent; PGM - Plant Grain Mass; HIH - Head Insertion Height; PH - Plants Height; NFT - Number of Fertile Tillers; SBHS - Spacing Between Head Spikelets; SN - Spikelets Number and HL - Head Length. 
The trait $\mathrm{HIH}$ reduction was revealed (Table 4) throughout combinations Tbio Mestre $\times$ Quartzo $\left(\hat{r}_{i j}=-1.31\right)$ and Tbio Mestre $\times$ Pampeano $\left(\hat{r}_{i j}=\right.$ 3.16) using the genotype Tbio Mestre as male parent and the combinations Quartzo $\times$ Pampeano $\left(\hat{r}_{i j}=-\right.$ 1.78) and Quartzo $\times$ Cep Horizonte $\left(\hat{r}_{i j}=-1.37\right)$, both with Quartzo genotype being the pollen donor.

The significant reciprocal effect verified in Tbio Mestre $\times$ Quartzo and Tbio Mestre $\times$ Pampeano crosses, can be the result of a significant non-maternal reciprocal component present in the crossings Tbio Mestre $\times$ Quartzo (-1.25) and Tbio Mestre $\times$ Pampeano (-1.68) (Table 5), respectively. The reciprocal effect observed in Quartzo $\times$ Cep Horizonte combination (Table 5), possibly occurred due to the significant maternal reciprocal effect of Cep Horizonte (-0.53).

If the decrease of wheat plant height is the goal, the combinations Tbio Mestre $\times$ Pampeano $\left(\hat{r}_{i j}\right.$ $=-3.60)$ and Quartzo $\times$ Pampeano $\left(\hat{r}_{i j}=-2.32\right)($ Table 4) must be used, both having the genotype Pampeano as a pollen receptor. This behavior was probably obtained for the crossing Tbio Mestre $\times$ Pampeano, as a function of the significant nonmaternal reciprocal effect detected for Tbio Mestre $\times$ Pampeano crossing (-2.2) (Table 5) and for Quartzo $\times$ Pampeano for the maternal reciprocal effect showed by Quartzo genotype (-0.63) (Table $5)$.

In order to increase the number of fertile tillers, the combination Quartzo $\times$ Cep Horizonte $\left(\hat{r}_{i j}\right.$ $=2.75$ ) must be prioritized, where Cep Horizonte is used as female parent (Table 4). This performance is possibly related to the significant non-maternal reciprocal effect evidenced by the crossing Quartzo $\times$ Cep Horizonte (3.41) (Table 5). When decreasing the spacing between head spikelets is the goal, it must prioritize the combination Pampeano $\times$ Cep Horizonte $\left(\hat{r}_{i j}=-0.57\right)$, where the genotype $\mathrm{Ce}$ Horizonte must be used as female parent and the combination Mirante $\times$ Pampeano $\left(\hat{r}_{i j}=-0.15\right)$, with the genotype Pampeano used as female parent (Table 4). Regarding the combination Pampeano $\times$ Cep Horizonte, it is observed that the reciprocal effect may have occurred due to the maternal effect presented by the genotypes Pampeano (-0.07) and Cep Horizonte (-0.05) (Table 5). Otherwise, the reciprocal effect observed for the combination
Mirante $\times$ Pampeano probably is related to the significant non-maternal effect obtained for this combination (Table 5).

When the increment in the number of spikelets per head is the objective, the combination Quartzo $\times$ Pampeano $\left(\hat{r}_{i j}=0.65\right)$ must be used, with Pampeano a female parent and the combination Mirante $\times$ Quartzo $\left(\hat{r}_{i j}=1.26\right)$ and Mirante $\times$ Cep Horizonte $\left(\hat{r}_{i j}=0.98\right)$, with the genotype Mirante being used as male parent (Table 4). The reciprocal effect of the crossing Quartzo $\times$ Pampeano is possibly expressed due to the non-maternal effects showed for this combination (Table 5). For the reciprocal effect of the combinations Mirante $\times$ Quartzo and Mirante $\times$ Cep Horizonte, maternal effects were present, since Mirante (0.55) was common for both combinations (Table 5).

By prioritizing the increase of wheat head length, it is possible to use the combinations Mirante $\times$ Quartzo $\left(\hat{r}_{i j}=0.74\right)$ and Mirante $\times$ Cep Horizonte $\left(\hat{r}_{i j}=0.46\right)$, both with the genotype Mirante being used as male parent (Table 4). The significant reciprocal effect revealed to Mirante $\times$ Quartzo (Table 5), can be explained by the significant maternal effect presented by Mirante (0.25) and by the combination Mirante $\times$ Cep Horizonte, from the maternal effect revealed by Cep Horizonte (0.31).

\section{Conclusions}

The parent Cep Horizonte high elevated combining ability for plant grain mass Quartzo and Mirante maximized the head spikelets number and head length. Tbio Mestre shows lower head insertion height, plant height and the spacing between head spikelets.

The reciprocal effect study demonstrate differentiations to the selection of pollen donor or receptor parent, with cytoplasmic and nucleus effects from female parent on the evaluated traits.

\section{Acknowledgments}

The authors thanks the Brazilian Council for Scientific and Technological Development (CNPq), Brazilian Federal Agency for Support and Evaluation of Graduate Education (CAPES) and RS State Foundation for Research Support (FAPERGS) for grants and fellowships. 


\section{References}

ALLARD, R.W.1999. Principles of plant breeding. New York: John Wiley.

ALVARES, C.A.; STAPE, J.L.; SENTELHAS, P.C.; GONÇALVES, J.L.; DE, M.; SPAROVEK, G. 2013. Köppen's climate classification map for Brazil. Meteorologia, 22:711-728.

BHULLAR, G.S.; GILL, K.S.; KHEHRA, A.S.1979 Combining ability analysis over $\mathrm{F}_{1}-\mathrm{F}_{5}$ generations in diallel crosses of bread wheat. Theoretical and Applied Genetics, 55:77-80.

BOROJEVIC, S. 1968. Characteristics of some new dwarf and semidwarf wheat lines. Euphytica, 17:14351.

CARVALHO, F.I.F. AND DOTTO, S.R. 1975. Competição de genótipos de trigo. In: Resultados dos trabalhos experimentais desenvolvidos na Estação Experimental Agronômica/UFRGS. S.i, s.ed.

CRUZ, C.D; REGAZZI, A.J.; CARNEIRO, P.C.S. 2012. Modelos biométricos aplicados ao melhoramento genético. Viçosa, UFV, 668p.

FEDERER, W.T. 1956. Augmented designs. Hawaiian Planter's Record, 55:191-208.

GOMES, M.S.; VON PINHO, E.V.R.; VON PINHO, R.G.; VIEIRA, M.G.G.C. 2000. Estimativas da capacidade de combinação de linhagens de milho tropical para qualidade fisiológica. Ciência Agrotécnica, 24:41-49.

GONDIM, T.C.O.; ROCHA, V.S.; SEDIYAMA, C.S.; MIRANDA, G.V. 2008. Análise de trilha para componentes do rendimento e caracteres agronômicos de trigo sob desfolha. Pesquisa Agropecuária Brasileira, 43:487-493.

GRIFFING, B. 1956. Concept of general and specific combining ability in relation to diallel crossing systems. Australian Journal of Biological Sciences, 9:463-493.

JUNG, M.S.; VIEIRA, E.A.; BRANCKER, A.; NODARI, R.O. 2007. Capacidade geral e específica de combinação de caracteres do fruto do maracujazeiro doce (Passiflora alata Curtis). Ciência Rural, 37:963-969.

KOSTETZER, V.; MOREIRA, R.M.P.; FERREIRA, J.M. 2009. Cruzamento dialélico parcial entre variedades locais do Paraná e variedades sintéticas de milho. Pesquisa Agropecuária Brasileira, 44:1152-1159.

KOTZAMANIDIS, S.T.; LITHOURGIDIS, A.S.; MAVROMATIS, A.G.; CHASIOTI, D.I.; ROUPAKIAS, D.G. 2008. Prediction criteria of promising $F_{3}$ populations in durum wheat: a comparative study. Field Crop Research, 107:257-264.

KUREK, A.J.; CARVALHO, F.I.F.; ASSMANN, I.C.; CRUZ, P.J. 2001. Capacidade combinatória como critério de eficiência na seleção de genitores em feijoeiro. Pesquisa Agropecuária Brasileira, 36:645-651.

LAUDE, H.H.; PAULI, A. 1956. Influence of lodging on yield and other characters in winter wheats. Agronomy Journal, 48:452-5. 
LORENCETTI, C.; CARVALHO, F.I.F.; BENIN, G.; MARCHIORO, V.S.; OLIVEIRA, A.C.; SILVA, J.A.G.; HARTWIG, I.; SCHMIDT, D.A.M.; VALÉRIO, I.P. 2005. Capacidade combinatória e heterose em cruzamento dialélico de aveia (Avena sativa L.). Revista Brasileira Agroctecnologia, 11:143-148.

MASOOD, M.S.; KRONSTAD, W.E. 2000. Combining ability analysis over various generations in a diallel cross of bread wheat. Pakistan Journal of Agricultural Sciences, 16:1-4.

MUKANGA, M.; DERERA, J.; TONGOONA, P. 2010.Gene action and reciprocal effects for ear rot resistance in crosses derived from five tropical maize populations. Euphytica, 174:293-301.

PÁDUA, T.R.P.; GOMES, L.A.A.; MALUF, W.R.; CARVALHO FILHO, J.L.S.; NETO, Á.C.G.; ANDRADE, M.C. 2010. Capacidade combinatória de híbridos de tomateiro de crescimento determinado, resistentes a Begomoviruse Tospovirus. Pesquisa Agropecuária Brasileira, 45:818825 .

PIMENTEL, A.J.B.; SOUZA, M.A.D.; CARNEIRO, P.C.S.; ROCHA, J.R.D.A.S.; MACHADO, J.C.; RIBEIRO, G. 2013. Análise dialélica parcial em gerações avançadas para seleção de populações segregantes de trigo. Pesquisa Agropecuaria Brasileira, 48:1555-1561.

PLARRE, W. 1975. Cultivation of wheat and barley in tropics and subtropics. Pl. Res. and Development, 2:67-79.

RAMALHO, M.A.P.; ABREU, A.F.B.; SANTOS, J.B.; NUNES, J.A.R. 2012. Aplicações da genética quantitativa no melhoramento de plantas autógamas. Lavras, UFLA, 522p.

RAMALHO, M.A.P.; SANTOS, J.B.; ZIMMERMANN, M.J.O. 1993. Genética quantitativa em plantas autógamas: aplicações ao melhoramento do feijoeiro. Goiânia, UFG, 271p.

RCBPTT. 2014. Informações técnicas para trigo e triticale - safra 2015. VIII Reunião da Comissão Brasileira de Pesquisa de Trigo e Triticale - Brasília, DF: Embrapa.

RIBEIRO, G.; SILVEIRA, G.; CRESTANI, M.; NORNBERG, R.; LUCHE, S.H.; MEZZALIRA, I.; CARVALHO, F.I.F.; OLIVEIRA, A.C. 2011. Diallel analysis in White oat cultivar subjected to water stress. Crop Breeding and Applied Biotechnology, 11:25-132.

ROCHA, F.; STINGHEN, J.C.; GEMELI, M.S.; COIMBRA, J.L.M.; GUIDOLIN, A.F. 2014. Análise dialélica como ferramenta na seleção de genitores em feijão. Revista Ciência Agronômica, 45:7481 .

RODRIGUES, O.; TEIXEIRA, M.C.C.; COSTENARO, E.R.; SANA, D. 2011. Ecofisiologia de trigo: bases para o elevado rendimento de grãos. In: Trigo no Brasil: Bases para a produção competitiva e sustentável'. (Eds JLF Pires, L Vargas, GR Cunha) pp. 427-451. Passo Fundo: Embrapa Trigo.

RODRIGUES, R.; LEAL, N.R.; PEREIRA, M.G. 1998. Análise dialélica de seis características agronômicas em Phaseolus vulgaris L. Bragantia, 57:241-250.

SANTOS, H.G.; JACOMINE, P.K.T.; ANJOS, L.H.C.; OLIVEIRA, V.A.; OLIVEIRA, J.B.; COELHO, M.R.; LUMBRERAS, J.F.; CUNHA, T.J.F. 2006. Sistema brasileiro de classificação de solos. Rio de Janeiro: Embrapa Solos.

SCHEEREN, P.L.; CARVALHO, F.I.F.; FEDERIZZI, L.C. 1981. Componentes da estatura de planta em trigo. Pesquisa Agropecuária Brasileira, 16:527-538. 
SCHMIDT, D.A.M. 2008. Capacidade combinatória e modificações de ambiente na expressão dos componentes do rendimento de grãos e da qualidade industrial em trigo. $111 \mathrm{f}$. Tese (Doutorado em Ciências). Universidade Federal de Pelotas - UFPEL, Pelotas.

SIBIYA, J.; TONGOONAA, P.; DERERAA, J.; RIJB, N.V.; MAKANDA, I. 2011. Combining ability analysis for Phaeosphaeria leaf spot resistance and grain yield in tropical advanced maize inbred lines. Field Crops Research, 120:86-93.

SILVA, M.P.; JÚNIOR, A.T.A.; RODRIGUES, R.; DAHER, R.F.; LEAL, N.R.; SCHUELTER, A.R. 2004. Análise dialélica da capacidade combinatória em feijão-de-vagem. Horticultura Brasileira, 22:277-280.

SOUZA, V.Q.; NARDINO, M.; BONATO, G.O.; BAHRY, C.A.; CARON, B.O.; ZIMMER, P.D.; SCHMIDT, D. 2013. Desfolha em diferentes estádios fenológicos sobre características agronômicas em trigo. Bioscience Journal, 29:905-1911.

VALÉRIO, I.P.; CARVALHO, F.I.F.; OLIVEIRA, A.C.; LORENCETTI, C.; SOUZA, V.Q.; SILVA, J.A.G.; HARWING, I.; SCHMIDT, A.M.; BERTAN, I.; RIBEIRO, G. 2009. Estabilidade da produção e da capacidade de combinação de diferentes populações de aveia. Semina: Ciências Agrárias, 30:331-346.

VOGEL, O.A.; CRADDOCK JUNIOR, J.C.; MUIR, C.E.; EVERSON, E.H.; ROHDE, C.L. 1956. Semidwarf growth habit la winter wheat improvement for the pacific northwest. Agronomy Journal, 48:76-78.

WU, H.X. AND MATHESON, A.C. 2001. Reciprocal, maternal and nonmaternal effects in radiata pine diallel mating experiment on four Australia sites. Forest Genetics, 8:205-212.

ZHANG, Y.; KANG, M.S.; LAMKEY, K.R. 2005. DIALLELSAS05: a comprehensive program for Griffing's and Gardner-Eberhart analyses. Agronomy Journal, 97:1097-1106.

Table 1 Supplementary. Genotypes, institution, release year and genealogies from parents present in the artificial crossings

\begin{tabular}{cccc}
\hline Cultivars & Genealogy & Breeder & Release Year \\
\hline Tbio Mestre & IBIO0810/Cronox//ORL00255 & Biotrigo & 2012 \\
\hline Mirante & Ônix/Taurum/Ônix & OR/Biotrigo & 2008 \\
\hline Quartzo & Ônix/Avante & OR/Biotrigo & 2007 \\
\hline Pampeano & ORL91274/ORL93807//ORL95711'S & OR & 2004 \\
\hline Cep Horizonte & BRS 119/CEP 97184 & CCGL - Fundacep & 2009 \\
\hline
\end{tabular}

Source: RCBPTT, 2014. 